\title{
Does size matter? Bumblebee behaviour and the pollination of Cytisus scoparius L. (Fabaceae)
}

\author{
Jane Catherine STOUT \\ Division of Biodiversity and Ecology, School of Biological Sciences, \\ University of Southampton, Bassett Crescent East, Southampton, SO16 7PX, UK
}

(Received 15 June 1999; revised 18 October 1999; accepted 6 November 1999)

\begin{abstract}
The effects of forager body size and floral display size on pollinator behaviour were assessed in a relatively specialised plant-pollinator system. Cytisus scoparius, which has structurally complex, nectarless flowers is pollinated by foraging bumblebees. Variations in bee body size affected the proportion of open flowers visited, the ability of bees to trigger the pollination mechanism of flowers and handling times on open flowers. Smaller bees handled flowers more successfully and efficiently than larger ones. Contrary to previous reports, all bees preferred to visit open flowers and possible explanations for this are discussed. Floral display size also affected behaviour as bees visited more flowers per plant on larger plants, but visited a lower proportion of the available flowers. There was no interaction between body size and floral display size, suggesting that bees of all sizes respond in a similar manner to variations in floral display sizes. The potential impacts of variations in bumblebee behaviour on plant reproductive success are discussed.
\end{abstract}

foraging behaviour / pollination / body size / floral display size / Bombus spp.

\section{INTRODUCTION}

Although the plant-pollinator system has been repeatedly viewed as a classic example of an ecological mutualism, conflicts within the system have caused evolutionary changes in both plants and their pollinators. Plants have tended to evolve to attract a high quantity and quality of pollinator service, and pollinators to maximise their foraging success (in terms of net energy gain). Specific attention has been given to how the size of various aspects of the plant-pollinator system have changed in response to selection pressures. For example it has been observed that insect foragers exhibit higher rates of visitation to larger flowers $[6,8,10$, $17,20,21,36,49]$, and flower size is

\footnotetext{
* Correspondence and reprints
}

E-mail: jcs3@ soton.ac.uk 
frequently correlated with the size of the floral reward (nectar and/or pollen) $[5,10$, $16,51,54]$. Furthermore, foragers tend to select and visit more flowers on plants or patches with large floral display sizes in order to reduce travel times between flowers $[3,22,23,32,46,47]$.

An increase in the size of floral characteristics, however, results in a trade-off between costs and benefits for the plant. The production of more flowers which are larger and have greater nectar and/or pollen rewards increases pollinator attraction but is more costly for the plant and may result in other disadvantages in terms of the quality of the pollination service received. For example, plants with a large floral display attract more foragers, but these pollinators can increase within-plant pollen transfer (geitonogamy) [15, 24, 26, 30, 41, 43]. Thus female success may be reduced in selfincompatible plants by self-pollen clogging stigmas and interfering with outcross pollen, and in self-compatible plants by inbreeding $[22,29]$. Male success may be affected by a reduction in pollen export to other plants [24, 34].

Similarly, variations in the size of morphological characteristics of pollinators can affect their ability to extract rewards from flowers of different sizes and may affect pollen collecting habits $[4,13,19]$. Large foragers with broad heads or shorter tongues cannot reach as far into corolla tubes as smaller ones with narrow heads. Larger foragers are therefore limited to more open flowers or flowers with shorter, wider corolla tubes [53]. Bumblebee (Bombus Latreille, Hymenoptera: Apidae) pollinators show body size variation at a range of scales. Body size varies among species, within the same species and even among individuals within a single colony $[2,7]$. Bumblebee colonies are founded annually by large mated queens which produce workers of various sizes throughout the season [1]. The average size of workers is thought to increase as the season progresses [38,
45], but despite this, different sized bumblebees of the same species often forage alongside each other. Bees of varying sizes regulate their body temperature differently [25] and this may affect foraging strategies on different sized plants. Smaller bees have a more rapid rate of passive heat loss and this may influence the amount of time spent on a plant and the number of flowers visited.

Size variations are particularly important in specialised plant-pollinator systems such as the pollination of Cytisus (Sarothamnus) scoparius L. (Fabaceae) by bumblebees. The large (16-20 mm) yellow flowers of C. scoparius have an explosive pollination mechanism, remaining closed until an insect alights on the wings and triggers the opening of the keel, and remaining open thereafter. The style and stamens are then released, collecting and depositing pollen on both the dorsal and ventral surfaces of the visitor [28]. Bumblebees are most effective at triggering the pollination mechanism, especially heavier species such as Bombus terrestris (L.) and B. lapidarius (L.) [33]. Pollen is also collected from open flowers by honeybees (Apis mellifera L. Hymenoptera: Apidae) and hover-flies (Diptera: Syrphidae) [27, 33]. Parker [37] found, however, that secondary visitors to open flowers did not contact the stigmatic surface and were unlikely to pollinate flowers. Flowers are nectarless, but open flowers display nectar guides which fool bees into attempting to probe for nectar [28]. Knuth [33] reported that bees hardly ever settle on flowers which have already been opened, but preliminary observations suggested that this is not necessarily the case (J.C. Stout personal observation).

Although the anthers and stigma mature at the same time in this plant species, flowers are not capable of passive self-pollination and flowers which are not visited rarely form pods $[14,33]$. Flowers which are fertilised with pollen from another plant are more likely to produce fruit than self-pollinated 
flowers [14, 37]. Since $C$. scoparius relies entirely on seeds for reproduction, and is severely pollinator limited, pollinator behaviour represents an important aspect of the reproductive biology of this plant species [37]. C. scoparius flowers throughout May and early June [18, 28], and hence both queens (the largest, and heaviest bumblebees) and smaller workers are potential pollinators. This system is therefore pertinent for investigating the influence of pollinator body size and floral display size on foraging behaviour. Although there have been many studies of the effects of floral display size on pollinator behaviour, there have been very few which have examined whether different sized bees of the same species differ in their foraging behaviour $[12,35]$. I tested the following hypotheses. Firstly, that bumblebee body size affects: a) choice of flower (open versus closed), b) success at handling flowers and c) handling time per flower; and secondly that plant size affects: a) the number of flowers visited per plant and $b$ ) the proportion of available flowers visited.

\section{MATERIALS AND METHODS}

\subsection{Field observations}

Bumblebees were observed foraging on 17 C. scoparius plants at two sites: five plants in the research gardens of the University of Southampton Research Centre at Chilworth and 12 plants in an area of open scrub-land at Lordswood. The sites are approximately $2.5 \mathrm{~km}$ apart, near Southampton (Hampshire, UK: 50 ${ }^{\circ} 57^{\prime} \mathrm{N}, 1^{\circ} 26^{\prime} \mathrm{W}$ ). Over six days (13 to 21 May 1997), 113 individuals of two species (99 B. terrestris and 14 B. lapidarius) were observed foraging on these plants.

Individual bees were monitored from their arrival at a plant to their departure and the following was noted: a) the state of the flowers visited (open or closed), b) the success of the bee if on a closed flower (i.e. triggering or not triggering the mechanism) and c) time spent per flower. Bees of both species were placed into three size categories: less than $15 \mathrm{~mm}$ long, between 15 and $20 \mathrm{~mm}$ long and greater than $20 \mathrm{~mm}$ long. Body lengths were estimated by eye whilst bees were foraging. A sample of 20 bees was captured on the first day of observation and their lengths measured to confirm estimations. The smallest size category probably contained the oldest workers whilst the largest size category contained only queens. Three cuckoo-bumblebees (Psithyrus spp. Lepeletier, Hyme-noptera: Apidae), one $B$. pratorum (L.) and one $B$. pascuorum (Scopoli) were also seen foraging on the plants, but were not included in the analysis. Five honeybees were also noted foraging on open flowers only, but were also not included in the analyses.

The size of the plant on which the bees were foraging was classified by counting the number of flowers available on each day that observations were made. On large plants with several hundred or thousands of flowers, the number of flowers was estimated to the nearest 50. Plants displayed a consistent number of flowers throughout the time observations were made.

\subsection{Data analysis}

Data from behavioural observations were pooled for the two sites as there was not sufficient within-site replication to analyse them separately. Furthermore, the two sites were close enough that bees could travel between them and in both sites the $C$. scoparius plants were the only major forage resources. Behaviour is, therefore, unlikely to have differed greatly between sites. The number of visits by bumblebees to open flowers was analysed as a proportion of the total number of flowers visited per bee using binomial errors in GLIM (version 3.77, Royal Statistical Society) according to bee species, body length and the interaction between them. Factors which did not contribute significant 
effects to the model were removed in a stepwise manner. As the ratio of the residual standard deviation to the residual degrees of freedom was less than 1.5, the test statistics given are $\chi^{2}$ values [9]. Similarly, the number of successful visits to closed flowers by each bee was analysed as a proportion of all its visits to closed flowers.

For each individual bee, I calculated the average time spent handling open flowers, closed flowers which were not triggered and closed flowers which were triggered. The average times spent handling flowers were $\log$ transformed to reduce heterogeneity of variance and were analysed using normal errors in GLIM according to body length, flower state and the interaction between them. Factors which did not contribute significant effects to the model were removed in a stepwise manner. For each individual bee, handling times on one flower type only were used in the analysis to prevent repeated measurements of individuals. Only handling times by $B$. terrestris were used in this analysis because there were not enough observations of $B$. lapidarius behaviour for analysis. To investigate whether there were any differences in handling times between the two species, mean times spent on open flowers were analysed according to bee species, body length and the interaction between species and body length in GLIM. It was not possible to repeat this analysis for closed flowers because of the small number of $B$. lapidarius observations.

The number of flowers visited per plant by each individual bumblebee was analysed with Poisson errors according to bee species, body length and floral display size (plus interactions) using GLIM. Since Poisson errors were used, test statistics given are $\chi^{2}$ values [9]. Again, factors which did not contribute significant effects to the model were removed. The proportion of flowers visited per plant was similarly analysed using binomial errors in GLIM and test statistics given are $\chi^{2}$ values as above.

\section{RESULTS}

Bumblebees of both species visited a high proportion of open flowers during a foraging bout but large bees visited more open flowers than smaller bees (Fig. 1). There was no significant interaction between bee species and body length, nor were the two bumblebee species different, but body length significantly affected the proportion of open flowers visited during a foraging bout (Tab. I). Body length also affected the triggering success of bees foraging on closed flowers. Smaller bumblebees were more successful than large ones at handling flowers and none of the three large bees that visited closed flowers triggered the pollination mechanism (Fig. 2), whereas small and medium-sized

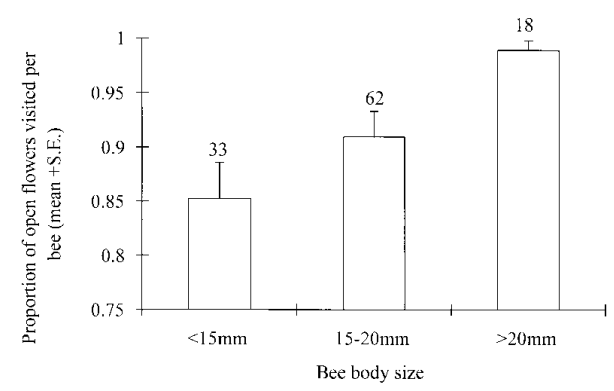

Figure 1. The effect of bumblebee size on the proportion of open flowers visited (data from both species are pooled). Numbers above bars indicate sample sizes.

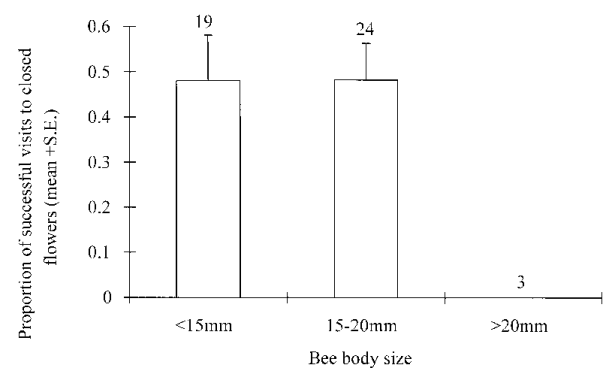

Figure 2. The proportion of successful visits to closed flowers by bumblebees of different body lengths (data from both species are pooled). Numbers above bars indicate sample sizes. 
Table I. The effect of bee species (B. terrestris, B. lapidarius) and body length $(<15 \mathrm{~mm}, 15-20 \mathrm{~mm}$, $>20 \mathrm{~mm}$ ) on the proportion of open flowers visited during a foraging bout and the proportion of successful triggering visits to closed flowers.

\begin{tabular}{lccccccc}
\hline & \multicolumn{3}{c}{$\begin{array}{c}\text { Visits to open } \\
\text { flowers }\end{array}$} & & & \multicolumn{3}{c}{$\begin{array}{c}\text { Successful visits } \\
\text { to closed flowers }\end{array}$} \\
\cline { 2 - 4 } \cline { 7 - 8 } & $\chi^{2}$ & d.f. & $p$ & & $\chi^{2}$ & d.f. & $p$ \\
\hline $\begin{array}{l}\text { bee spp. } \times \text { body length } \\
\text { bee species }\end{array}$ & 1.72 & 2 & 0.423 & & 0.00 & 2 & 1.00 \\
body length & 0.75 & 1 & 0.386 & & 0.00 & 1 & 1.00 \\
\hline
\end{tabular}

Significant effects are marked with asterisks.

bees triggered closed flowers $48 \%$ of the time on average. Again, the two bee species were equally successful at opening closed flowers and there was no significant interaction between terms (Tab. I).

Bees (B. terrestris only) tended to spend more time on closed flowers which they triggered compared with open ones or closed ones which they did not trigger (Fig. 3). Flower handling times varied significantly with flower type but not with body length (Tab. II). When the handling times of B. terrestris and $B$. lapidarius on open flowers were compared, smaller bees handled flowers more quickly than larger bees (Fig. 4), but there was no significant difference between species (Tab. III).

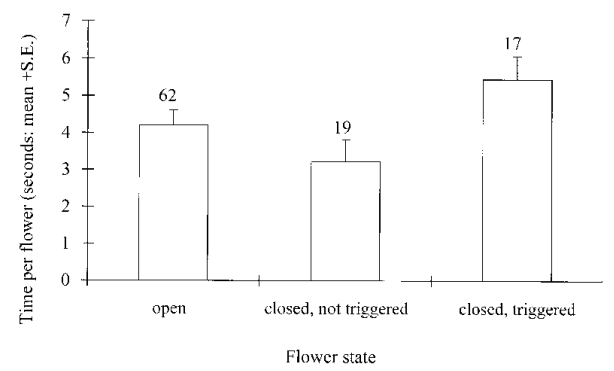

Figure 3. B. terrestris handling times on open and closed flowers. Closed flowers were either not triggered and remained closed, or triggered successfully and opened following a visit. Numbers above bars indicate sample sizes.
The two bee species visited approximately the same numbers of flowers per plant, and all bees visited more flowers per plant on plants with large floral display sizes (Tab. IV and Fig. 5). Increases in the number of flowers visited per plant with increasing floral display size were not enough to match increases in the number of available flowers. Hence bees visited a decreasing proportion of the available flowers as the number of flowers per plant increased (Fig. 6, Tab. IV).

\section{DISCUSSION}

Foraging behaviour was affected by body size in both species. B. terrestris and B. lapidarius are morphologically very similar [1] and so size was not confounded by bee species in the analyses. It has previously been shown that bumblebees exhibit considerable size-variation, but few studies have shown that this affects foraging behaviour. Morse [35] showed that bumblebee (B. vagans) body size was positively correlated with flower (Vicia cracca) size and concluded that this occurred because individual bees were maximising foraging efficiency. I found that when foraging on C. scoparius, body size affected floral choice (in terms of the type of flowers selected), the ability of bees to trigger the pollination mechanism and handling times. Classic 
pollination texts [for example see 27,28 , 33 ] state that larger, heavier bees are more effective at triggering the complex pollination mechanism of C. scoparius flowers. However, I found that large bees visited far

Table II. The effects of body length $(<15 \mathrm{~mm}$, $15-20 \mathrm{~mm},>20 \mathrm{~mm}$ ) and flower state (open, closed and not triggered, closed and triggered) on handling times by $B$. terrestris.

\begin{tabular}{llcc}
\hline & $F$ & d.f. & $p$ \\
\hline body length $\times$ flower & & & \\
state & 0.556 & 3,90 & 0.645 \\
body length & 1.959 & 2,93 & 0.147 \\
flower state & 6.01 & 2,93 & $0.004^{* *}$ \\
\hline
\end{tabular}

Significant effects are marked with asterisks.

Table III. The effect of bee species (B. terrestris, $B$. lapidarius) and body length $(<15 \mathrm{~mm}$, $15-20 \mathrm{~mm},>20 \mathrm{~mm}$ ) on handling times on open flowers.

\begin{tabular}{lccc}
\hline & $F$ & d.f. & $p$ \\
\hline $\begin{array}{c}\text { bee species } \times \\
\text { body length }\end{array}$ & 1.04 & 2,109 & 0.357 \\
$\begin{array}{c}\text { bee species } \\
\text { body length }\end{array}$ & 0.17 & 1,109 & 0.681 \\
& 3.53 & 2,109 & $0.033^{*}$
\end{tabular}

Significant factors are marked with an asterisk. more flowers already triggered by other bees and, when they attempted to trigger closed flowers, they consistently failed. At least two factors could explain this finding. Small bumblebees are relatively large compared with other British bee species [40], and they may be more suited to the flowers of $C$. scoparius (which are 16-20 $\mathrm{mm}$ in length) than the larger queen bumblebees. Large queen bees (typically 20-25 mm [1]) may be physically unable to trigger the floral mechanism because they are too big. Alternatively, it may be due to the foraging differences between queens and workers at this time of year. Queen bumblebees collect less pollen as the season progresses [39], and so they

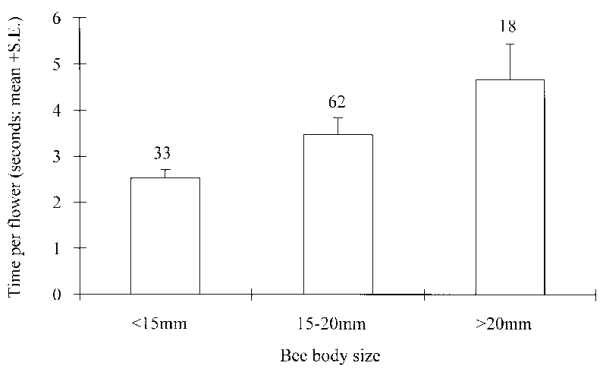

Figure 4. The effect of body size of $B$. terrestris and $B$. lapidarius on handling times on open flowers. Numbers above bars indicate sample sizes.

Table IV. The effect of bee species (B. terrestris, B. lapidarius), body length ( $<15 \mathrm{~mm}, 15-20 \mathrm{~mm}$, $>20 \mathrm{~mm}$ ), and floral display size $(<151,151-500,500-1500,>1500$ flowers $)$ on the number and proportion of flowers visited per plant.

\begin{tabular}{|c|c|c|c|c|c|c|}
\hline & \multicolumn{3}{|c|}{$\begin{array}{l}\text { Number of flowers } \\
\text { visited per plant }\end{array}$} & \multicolumn{3}{|c|}{$\begin{array}{l}\text { Proportion of flowers } \\
\text { visited per plant }\end{array}$} \\
\hline & $\chi^{2}$ & d.f. & $p$ & $\chi^{2}$ & d.f. & $p$ \\
\hline bee spp. $\times$ body length $\times$ floral display size & 0.98 & 3 & 0.806 & 0.74 & 3 & 0.864 \\
\hline bee spp. $\times$ body length & 0.83 & 2 & 0.660 & 1.11 & 2 & 0.574 \\
\hline bee $\mathrm{spp} . \times$ floral display size & 3.09 & 3 & 0.378 & 3.96 & 3 & 0.266 \\
\hline body length $\times$ floral display size & 1.88 & 5 & 0.866 & 1.59 & 5 & 0.902 \\
\hline bee spp. & 3.51 & 1 & 0.386 & 4.74 & 1 & $0.030 *$ \\
\hline body length & 2.74 & 2 & 0.254 & 2.04 & 2 & 0.361 \\
\hline floral display size & 9.24 & 3 & $0.026^{*}$ & 36.7 & 3 & $<0.001 * * *$ \\
\hline
\end{tabular}

Significant effects are marked with asterisks. 


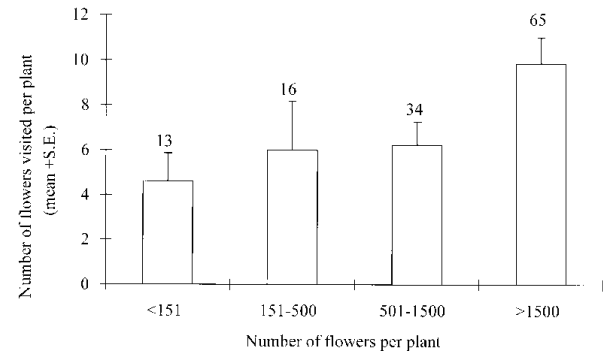

Figure 5. The effect of the size of the floral display on the number of flowers visited per plant. Numbers above bars indicate sample sizes.

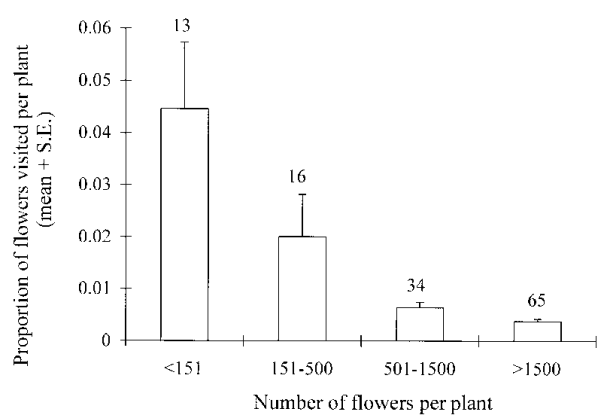

Figure 6. The proportion of available flowers visited per plant on plants with different numbers of flowers. Numbers above bars indicate sample sizes.

may not be as effective at pollen collection as smaller workers which spend much of their time harvesting pollen.

Handling times on open flowers were also affected by body size as smaller bees were faster on open flowers than larger ones. Again, this may be because the smaller bees are more suited to the flower size and so are more efficient. The smallest bees are also the oldest workers, have more foraging experience than medium sized bees and may therefore be quicker at handling the flowers. Body size did not affect $B$. terrestris handling times when all flower types were considered; the time taken to manipulate a flower varied according to the flower state. Handling time was greatest on closed flow- ers that the bee triggered. Thus bees of all sizes visited more open flowers which had already been triggered because they were quicker to handle. Alternatively, it may have been because there were more open flowers available than closed ones (J.C. Stout, personal observation) and bees may therefore handle open flowers more rapidly because they represent a more familiar flower type. Bees were quickest at handling closed flowers which they did not trigger. These flowers may have been still quite tightly closed and not ready to open. Bees may have tried to access these flowers and then departed when they were unsuccessful. Alternatively, these bees may have been inexperienced and they 'gave-up' on closed flowers because they were unaware of the potential pollen reward from previously unvisited flowers.

More than half of the bees observed $(59 \%)$ did not visit closed flowers during a foraging bout. This observation contradicts the belief that bees prefer to visit closed flowers [33]. There are at least three possible reasons for this. Firstly, as mentioned above, bees may visit more open flowers because they are more common than closed flowers. Bumblebees may select the most common flower types as this may reduce search and handling times $[42,50]$. Secondly, the large yellow corollas, with 'nectar-guides' which are only visible on triggered flowers, attract bees to probe for nectar. Different individual bees may specialise in collecting pollen or nectar or both [11] and a naïve nectar forager that visits C. scoparius may sample several flowers before departing without even attempting to open closed flowers. Certainly the nectar guides fool Psithyrus (cuckoo bumblebees) into probing for nectar since bees of this genus never forage for pollen [40]. A third reason why bees were selecting open flowers may be that they were detecting attractive scent marks deposited by previous foragers. Bumblebees have been shown to use attractive scents whilst foraging for nectar from artificial flowers, and 
preferentially visit flowers which have previously been visited by another bee [48] However, there is little evidence for bumblebees using attractive scent marks in the field [52] and there have been no investigations into the use of scent marks on nectarless flower species.

Floral display size affected bumblebee foraging behaviour. As in many other studies [for example 3, 22, 23, 32, 44, 46, 47], I found that bees of all sizes visited more flowers per plant on plants with a larger floral display, but visited a decreasing proportion of the flowers available. Contrary to the predictions based on differential energy expenditure by bees of different sizes, there was no interaction between plant size and body size. Different sized bees were not visiting different numbers of flowers per plant, possibly because ambient temperatures were relatively high when observations were made (J.C. Stout personal observation).

Previous work has shown that although plants with a larger floral display size attract more pollinators, increased inbreeding can cause a reduction in the number and mass of seeds produced [22, 29, 31]. Inbreeding in C. scoparius is known to severely affect seed set and progeny fitness [14, 37]. Visitation rates and pod set per plant were not measured in my study, but preliminary results indicated that seed set per pod and seed weight were not affected by floral display size (J.C. Stout, unpublished data). Bees visited a very small proportion of the available flowers on all plants (an average of 7.9 flowers were visited per plant) and hence within-plant pollen transfer (geitonogamy) and inbreeding would have been low on plants of all sizes.

In conclusion, there is a relatively specialised relationship between $C$. scoparius and its pollinators, and bumblebee foraging behaviour can have an important impact on the reproductive success of this plant species. Bumblebee foraging behaviour was found to be affected by both body size and floral display size. However, all bees visited a small number of flowers per plant, regardless of body size.

\section{ACKNOWLEDGEMENTS}

This work was funded by a Ph.D. studentship awarded to J.C. Stout by the University of Southampton. I am grateful to Drs. Dave Goulson, Tasman Crowe, John Allen and Bernard Vaissière for valuable comments on the manuscript.

Résumé - La taille importe-t-elle ? le comportement des bourdons (Bombus spp.) et la pollinisation de Cytisus scoparius (Fabaceae). Les effets de la taille corporelle de l'insecte butineur et de la taille de la fleur sur le comportement du pollinisateur ont été évalués dans un système plante-pollinisateur relativement spécialisé. Cytisus scoparius, le genêt à balais, qui possède des fleurs de structure complexe et dépourvues de nectar, est pollinisé par les bourdons. Sa fleur reste fermée jusqu'à ce qu'elle soit déclenchée par une visite positive de l'insecte; elle reste ensuite ouverte. J'ai étudié le comportement de butinage de deux espèces de bourdons, Bombus terrestris et Bombus lapidarius, sur C. scoparius. Les observations ont été faites près de Southampton (Hampshire, UK) en mai 1997. J'ai comparé le comportement de butinage de bourdons de taille variée et examiné les effets de la taille de la fleur sur le comportement du pollinisateur. À cette période de l'année de grosses reines et des ouvrières plus petites butinent activement. Contrairement aux études précédentes, j'ai trouvé que les bourdons se posaient principalement sur les fleurs déjà ouvertes, semblant préférer visiter les fleurs déjà déclenchées par un autre insecte (Fig. 1, Tab. I). Il se peut que les bourdons visitent plus de fleurs ouvertes que de fleurs fermées parce que 1) les fleurs ouvertes sont plus rapides d'accès et le pollen peut encore être récolté sur les anthères exposées, 2) les enseignes à nectar sur la corolle attirent les insectes à la recherche 
du nectar (bien que les fleurs en soient dépourvues), 3) sur les plantes il y a plus de fleurs ouvertes disponibles que de fleurs closes et 4) les insectes peuvent être attirées par des marques odorantes sur les fleurs qui ont été déjà visitées.

Les bourdons de taille petite et de taille moyenne réussissent mieux à déclencher les fleurs que ceux de grande taille (Fig. 2, Tab. I). Ceci contredit les rapports précédents selon lesquels les bourdons plus gros ont une plus grande efficacité pour déclencher le mécanisme de pollinisation de $C$. scoparius. Le temps de récolte de B. terrestris sur des fleurs ouvertes et des fleurs fermées n'a pas été affecté par la taille corporelle mais par l'état de la fleur (Fig. 3, Tab. II). Les bourdons avaient besoin de plus de temps sur les fleurs ouvertes. La taille corporelle a affecté le temps de récolte des deux espèces sur les fleurs ouvertes puisque les gros bourdons ont passé plus de temps que les petits (Fig. 4, Tab. III). Le comportement du pollinisateur a été également affecté par la taille de la plante : les bourdons ont visité plus de fleurs par plante sur les plantes de grande taille (Fig. 5, Tab. IV). Néanmoins une plus petite proportion de fleurs présentes sur les plantes de grande taille ont été visitées (Fig. 6, Tab. V). Il n'y a pas eu d'interaction entre la taille corporelle et la taille de la fleur, ce qui suggère que les insectes, quelle que soit leur taille, répondent de la même façon aux variations de la taille des fleurs.

butinage / pollinisation / taille corporelle / taille des fleurs / Bombus spp.

Zusammenfassung - Spielt die Größe eine Rolle? Das Verhalten von Hummeln und die Bestäubung von Cytisus scoparius $\mathbf{L}$. (Fabaceae). Der Einfluss der Körpergröße der Bestäuber und der Größe der Blüten auf das Verhalten der Bestäuber wurde in einem recht spezialisierten Pflanzen - Bestäuber System bestimmt. Cytisus scoparius, die komplex gebaute nektarlose Blüten hat, wird von sammelnden Hummeln bestäubt. Ihre Blüten bleiben geschlossen, bis ihre Öffnung durch einen erfolgreichen Hummelbesuch ausgelöst wird und bleiben danach offen. Das Verhalten von 2 Hummelarten (Bombus terrestris und B. lapidarius), die auf $C$. scoparius sammeln, wurde untersucht. Die Beobachtung fand in der Nähe von Southampton (Hampshire, England) im Mai 1997 statt. Ich verglich das Sammelverhalten von Hummeln verschiedener Größe und untersuchte den Effekt von der Blütengröße auf das Verhalten der Bestäuber und den Samenansatz. Zu dieser Jahreszeit sammeln beide Kasten, die großen Königinnen und die kleineren Arbeiterinnen. Im Gegensatz zu früheren Untersuchungen fand ich, dass sich Hummeln meistens auf offenen Blüten niederließen. Offensichtlich bevorzugten sie Blüten, deren Aufblühen bereits durch eine andere Biene ausgelöst war (Abb. 1, Tab. I).Aus folgenden Gründen scheinen Hummeln häufiger offene als geschlossene Blüten zu besuchen: (1) offene Blüten sind leichter zugänglich und es können immer noch Pollen von den freistehenden Antheren gesammelt werden, (2) die Saftmale auf den Blütenblättern verlocken Bienen nach Nektar zu suchen (obwohl die Blüten keine Nektar bieten), (3) es gibt mehr offene als geschlossene Blüten auf den Pflanzen und (4) vielleicht nehmen Bienen einen anziehenden Duft von Blüten wahr, die schon durch vorherigen Besuch geöffnet wurden. Kleine und mittelgroße Hummeln waren erfolgreicher bei der Auslösung des Öffnens der Blüte als große (Abb. 2, Tab. I). Das widerspricht früheren Berichten, dass große Hummeln den Mechanismus zur Bestäubung von $C$. scoparius erfolgreicher auslösen. Die Zeit des Sammelns von B. terrestris an offenen und geschlossenen Blüten wurde nicht durch die Körpergröße, sondern durch das Stadium der Blüte beeinflusst (Abb. 3, Tab. II). Hummeln benötigten mehr Zeit bei geschlossenen Blüten. Die Sammeldauer wurde bei beiden Arten durch die Körpergröße beeinflusst, da große Hummeln mehr 
Zeit als kleine benötigten (Abb. 4, Tab. III). Das Bestäubungsverhalten wurde aber auch von der Größe der Pflanze beeinflusst, denn Hummeln besuchten bei großen Pflanzen mehr Blüten pro Pflanze (Abb. 5, Tab. IV). Allerdings wurde ein geringerer Prozentsatz der bei den großen Pflanzen vorhandenen Blüten besucht (Abb. 6, Tab. IV). Es ergab sich keine Beziehung zwischen Körper- und Blütengröße, sodass angenommen werden kann, dass alle Bienen unabhängig von der Größe in gleicher Weise auf die unterschiedlichen Größen der Blüten reagieren.

\section{Sammelverhalten / Bestäubung / Körper- größe / Blütengröße / Bombus spp.}

\section{REFERENCES}

[1] Alford D.V., Bumblebees, Davis-Poynter Ltd, London, 1975.

[2] Alford D.V., The life of the Bumblebee, DavisPoynter, London, 1978.

[3] Andersson S., Size dependent pollination efficiency in Anchusa officinalis (Boraginaceae) causes and consequences, Oecologia 76 (1988) 125-130.

[4] Brian A.D., Division of labour and foraging in Bombus agrorum Fabricius, J. Animal Ecol. 21 (1952) 223-240.

[5] Brink D., Wet J.M.J. de, Interpopulation variation in nectar production in Aconitum columbianum (Ranunculaceae), Oecologia 47 (1980) 160-163.

[6] Campbell D.R., Inflorescence size, test of the male function hypothesis, Am. J. Bot. 76 (1989) 730-738.

[7] Cnaani J., Hefetz A., The effect of workers size frequency-distribution on colony development in Bombus terrestris, Insectes Soc. 41 (1994) 301-307.

[8] Conner J.K., Rush S., Effects of flower size and number on pollinator visitation to wild radish, Raphanus raphanistrum, Oecologia 105 (1996) 509-516.

[9] Crawley M.J., GLIM for ecologists, Blackwell Scientific Publications, Oxford, 1993

[10] Cresswell J.E., Galen C., Frequency-dependent selection and adaptive surfaces for floral character combinations: the pollination of Polemonium Viscosum, Am. Nat. 138 (1991) 1342-1353.

11] Cresswell J.E., Robertson A.W., Discrimination by pollen-collecting Bumblebees among differ- entially rewarding flowers of an alpine wildflower, Campanula rotundifolia (Campanulaceae), Oikos 69 (1994) 304-308.

[12] Cumber R.A., Biology of bumble-bees with special reference to the production of the worker caste, Trans. R. Entomol. Soc. Lond. 100 (1949) $1-45$.

[13] Dafni A., Kevan P.G., Flower size and shape: implications in pollination, Israel J. Plant Sci. 45 (1997) 201-212.

[14] Darwin C., The effects of cross and self fertilisation in the vegetable kingdom, John Murray, London, 1891.

[15] Dudash M.R., Plant size effects on female and male function in hermaphroditic Sabatia angularis (Gentianaceae), Ecology 72 (1991) 1004-1012.

[16] Duffield G.E., Gibson R.C., Gilhooly P.M., Hesse A.J., Inkley C.R., Gilbert F.S., Barnard C.J., Choice of flowers by foraging honeybees (Apis mellifera) - possible morphological cues, Ecol. Entomol. 18 (1993) 191-197.

[17] Eckhart V.M., The effects of floral display on pollinator visitation vary among populations of Phacelia linearis (Hydrophyllaceae), Evol. Ecol. 5 (1991) 370-384.

[18] Fitter R., Fritter A., Blamey M., Wild flowers of Britain and North-eastern Europe (Fifth edition), Harper Collins, London, 1996.

[19] Free J.B., Butler C.G., Bumblebees, Collins, London, 1959.

[20] Galen C., Measuring pollinator-mediated selection on morphometric floral traits - Bumblebees and the alpine sky pilot Polemonium viscosum, Evol. 43 (1989) 882-890.

[21] Galen C., Newport M.E.A., Bumblebee behaviour and selection on flower size in the sky pilot, Polemonium viscosum, Oecologia 74 (1987) 20-23.

[22] Geber M.A., The relationship of plant size to self-pollination in Mertensia ciliata, Ecology 66 (1985) 762-772.

[23] Goulson D., Stout J.C., Hawson S.A., Allen J.A., Floral display size in comfrey, Symphytum officinale L. (Boraginaceae): relationships with visitation by three Bumblebee species and subsequent seed set, Oecologia 113 (1998) 502-508.

[24] Harder L.D., Barrett S.C.H., Pollen dispersal and mating patterns in animal-pollinated plants, in: Lloyd D.G., Barrett S.C.H. (Eds.), Floral biology: studies on floral evolution in animal pollinated plants, Chapman and Hall, New York, 1995, pp. 140-190.

[25] Heinrich B., Thermoregulation in Bumblebees. II. Energetics of warm-up and free flight, J. Comp. Physiol. (1975) 155-166.

[26] Hessing M.B., Geitonogamous pollination and its consequences in Geranium caespitosum, Am. J. Bot. 75 (1988) 1324-1333. 
[27] James W.O., Clapham A.R., The biology of flowers, Oxford University Press, London, 1935.

[28] Jones S.G., Introduction to floral mechanism, Blackie \& Son Ltd, 1950.

[29] Jong T.J. de, Waser N.M., Price M.V., Ring R.M., Plant size, geitonogamy and seed set in Ipomosis aggregata, Oecologia 89 (1992) 310-315.

[30] Jong T.J. de, Waser N.M., Klinkhamer P.G.L., Geitonogamy - the neglected side of selfing, Trends Ecol. Evol. 8 (1993) 321-325.

[31] Klinkhamer P.G.L., Jong T.J. de, Attractiveness to pollinators - a plants dilemma, Oikos 66 (1993) 180-184.

[32] Klinkhamer P.G. L., Jong T.J. de, De Bruyn G.J., Plant size and pollinator visitation in Cynoglossum officinale, Oikos 54 (1989) 201-204.

[33] Knuth P., Handbook of flower pollination based on Hermann Mueller's 'The fertilisation of flowers by insects', Clarendon Press, Oxford, 1906.

[34] Lloyd D.G., Some reproductive factors affecting the selection of self-fertilization in plants, Am. Nat. 113 (1979) 67-79.

[35] Morse D.H., Size-related foraging differences of bumblebee workers, Ecol. Entomol. 3 (1978) 189-192.

[36] Ohara M., Higashi S., Effects of inflorescence size on visits from pollinators and seed set of Corydalis ambigua (Papaveraceae), Oecologia 98 (1994) 25-30.

[37] Parker I.M., Pollinator limitation of Cytisus scoparius (Scotch broom), an invasive exotic shrub, Ecology 78 (1997) 1457-1470.

[38] Plowright R.C., Jay S.C., Caste differentiation in Bumblebees (Bombus Latr.: Hym.). 1. The determination of female size, Insectes Soc. 15 (1968) 171-192.

[39] Prys-Jones O.E., Ecological studies of the foraging and life history in Bumblebees, Ph.D. thesis, University of Cambridge, 1982.

[40] Prys-Jones O.E., Corbet S.A., Bumblebees, Richmond Publishing Co. Ltd., Slough, 1991.

[41] Rademaker M.C.J., Jong T.J. de, Klinkhamer P.G.L., Pollen dynamics of bumble-bee visitation on Echium vulgare, Funct. Ecol. 11 (1997) 554-563.

[42] Real L.A., Predator switching and the interpretation of animal choice behaviour: the case for constrained optimization, in: Hughes R.N. (Ed.), Behavioural mechanisms of food selection, Springer Verlag, Heidelberg, 1990, pp. 1-21.
[43] Robertson A.W., The relationship between floral display size and pollen carryover and geitonogamy in Myosotis colensoi (Kirk) Macbride (Boraginaceae), Biol. J. Linn. Soc. 46 (1992) 333-349.

[44] Robertson A.W., Macnair M.R., The effects of floral display size on pollinator service to individual flowers of Myosotis and Mimulus, Oikos 72 (1995) 106-114.

[45] Röseler P.F., Unterschiede in der Kastendetermination zwischen den Hummelarten Bombus hypnorum und Bombus terrestris, Z. Naturforsch. 25 (1970) 543-548.

[46] Schmid-Hempel P., Speiser B., Effects of inflorescence size on pollination in Epilobium angustifolium, Oikos 53 (1988) 98-104.

[47] Schmitt J., Flowering plant density and pollinator visitation in Senecio, Oecologia 60 (1983) 97-102.

[48] Schmitt U., Bertsch A., Do foraging Bumblebees scent-mark food sources and does it matter?, Oecologia 82 (1990) 137-144.

[49] Shykoff J.A., Bucheli E., Kaltz O., Anther smut disease in Dianthus silvester (Caryophyllaceae): natural selection on floral traits, Evolution 51 (1997) 383-392.

[50] Smithson A., Frequency-dependent selection amongst floral variants through the foraging behaviour of Bumblebees, Bombus terrestris, Ph.D. thesis, University of Exeter, 1995.

[51] Stanton M.L., Preston R., A qualitative model for evaluating the effects of flower attractiveness on male and female fitness in plants, Am. J. Bot. 75 (1988) 540-544.

[52] Stout J.C., Goulson D., Allen J.A., Repellent scent-marking of flowers by a guild of foraging Bumblebees (Bombus spp.), Behav. Ecol. Sociobiol. 43 (1998) 317-326.

[53] Suzuki K., Pollinator restriction in the narrowtube flower type of Mertensia ciliata (James) G. Don (Boraginaceae), Pl. Sp. Biol. 9 (1994) 69-73.

[54] Teuber L.R., Barnes D.K., Breeding alfalfa for increased nectar production, Proceedings of the IV International Symposium on Pollination, Maryland, 1979, pp. 109-116.

[55] Young H.J., Young T.P., Alternative outcomes of natural and experimental high pollen loads, Ecology 73 (1992) 639-647. 